\title{
Revelação e vulnerabilidade: caminhos para uma hermenêutica da revelação a partir da presença-ausência
}

\author{
Orientadora: Maria Clara Lucchetti Bingemer \\ Doutorando: Abdruschin Schaeffer Rocha \\ Área de Concentração: Teologia Sistemático-Pastoral \\ Linha de Pesquisa: Religião e Modernidade
}

A pesquisa objetiva refletir sobre as possibilidades de uma pretensa relação entre a revelação divina e a vulnerabilidade humana, propondo, para isso, "caminhos" para uma hermenêutica da revelação que se compreenda a partir do movimento dialético entre a presença e a ausência. Discute, portanto, se essa revelação diz respeito apenas ao divino e se tal vulnerabilidade é característica apenas do humano. Para tanto, parte-se do pressuposto de que a tradição ocidental, em grande medida, se constrói sobre pressupostos metafísicos que delineiam o horizonte a partir do qual se conceberá a revelação durante a maior parte do tempo. A Modernidade, que se ergue sobre essa lógica metafísica, altamente comprometida com o "desnudamento" do mundo, verá a revelação apenas como um processo por meio do qual aquilo que estava oculto se manifesta absoluta, plena e substanciamente, ou seja, assumirá a revelação apenas em seu caráter manifestacional, tornando-se, nesse sentido, refratária a qualquer interpretação que se conceba sob o signo do "mistério". Verifica-se, portanto, uma "inflação" da presença e do sentido que se materializa historicamente na cultura ocidental moderna, em geral, e no cristianismo, em particular. O cristianismo sob o influxo dessa "saturação" se organizará em torno da presença divina, metafisicamente concebida, e a partir de um discurso altamente apologético.

Mas, ao longo do percurso aqui proposto constatou-se, também, uma crítica exacerbada ao modo metafísico de se conceber o mundo e o surgimento de uma nova tradição que se insinua cada vez mais pós-metafísica, mediante a qual se considerará o tema aqui proposto. Resgata-se esse "horizonte teórico" a partir de importantes mudanças históricas ocorridas nos campos da linguagem, da hermenêutica e da pragmática (Linguistic Turn). Essa mudança de 
paradigmas repercutiu em diversas áreas das ciências humanas, inclusive na própria teologia. Destaca-se aqui a "dialética" inferida de Martin Heidegger e a "hermenêutica kenótica" proposta por Gianni Vattimo, importantes pensadores no contexto das mudanças que estabelecerão o pensamento pós-metafísico. Além deles, e na esperança de se consolidar o referencial teórico desta pesquisa, ressaltam-se três teólogos cujas reflexões serão significativamente influenciadas pela crítica ao pensamento metafísico: Karl Rahner, Edward Skillebeekx e Andrés Torres Queiruga.

Finalmente, mediante uma "hermenêutica da presença-ausência", a pesquisa propõe caminhos para a construção de uma teologia da revelação que se faça a partir da vulnerabilidade humana. Assume, nesse sentido, a recepção enquanto critério hermenêutico-teológico, ao sugerir uma teologia de "textos escritos" - amparada no pressuposto de que está circunscrita aos limites da linguagem —, bem como uma teologia de "textos vivos" - consciente de que há experiências humanas que extrapolam esses limites. Em ambos os casos pressupõe-se uma "epistemologia frágil", que proporcione lidar com esse caráter abscôndito e manifesto do divino ao modo de um "pastoreio". Ou seja, propõe-se que o processo através do qual somos interpelados por esse Deus que se expressa na dialética da presença-ausência, que aqui se nomeia de revelação, seja alvo do cuidado humano. Pastorear o divino; pastorear os meios através dos quais o compreendemos; pastorear o "produto final" desse processo, que se transforma em teologia; pastorear o próprio pastoreio; enfim, pastorear a revelação - eis aí o desafio proposto pela pesquisa.

Palavras-chave: Revelação. Vulnerabilidade. Hermenêutica. 